\title{
Feasibility Test Reconstruction of Ethical Enforcement Regulations for Election Organizers Based on the Values of Justice with Dignity
}

\author{
Muhammad Afied Hambali ${ }^{1 *}$, Teguh Prasetyo ${ }^{2}$, Widayati ${ }^{3}$, Muhammad Ngazis $^{3}$ \\ ${ }^{1}$ Doctorate Student of Faculty of Law Sultan Agung Islamic University Semarang, Indonesia \\ ${ }^{2}$ Faculty of Law Pelita Harapan University Jakarta, Indonesia \\ ${ }^{3}$ Faculty of Law Sultan Agung Islamic University Semarang, Indonesia
}

DOI: $10.36348 /$ sijlcj.2022.v05i01.001

| Received: 01.12.2021 | Accepted: 05.01.2022 | Published: 12.01.2022

*Corresponding author: Muhammad Afied Hambali

Doctorate Student of Faculty of Law Sultan Agung Islamic University Semarang, Indonesia

\section{Abstract}

In the context of building an ethical enforcement system for general election organizers in Indonesia, apart from the need to complete and reinforce the material for legislation, it is also important to question the effectiveness of the work of general election organizers. The organizers of the General Election have the authority to impose sanctions on perpetrators of violations of the General Election administration. The emergence of ethical enforcement problems for the organizers of the General Election, especially in Article 458 paragraph (13) and paragraph (14) of Law no. 7 of 2017 concerning General Elections, which explains that the DKPP's decision is final and binding, this can lead to legal uncertainty and cannot be equated with final and binding decisions from judicial institutions in general because DKPP is an internal election organizer that is authorized by law. The results of this study have theoretical implications, especially concerning the code of ethics in the administration of elections that has developed so far which views that laws and regulations apply as the only absolute recognized standard of truth. This study has practical implications, that state law needs to be adapted to the conditions and situations of this nation, not to the interests of certain parties. Enforcement of ethics as described in Law no. 7 of 2017 concerning General Elections. The substances regulated are obligations to the state, obligations to the community, integrity, independence, and professionalism of the General Election Organizer. Although there is no explicit mention of the obligation to honor a code of ethics that is implemented properly/not violated is expected to place the General Election Organizer in the highest honor.

Keywords: Reconstruction, Ethics Enforcement, Election Organizers, Dignified Justice.

Copyright (C) 2022 The Author(s): This is an open-access article distributed under the terms of the Creative Commons Attribution 4.0 International License (CC BY-NC 4.0) which permits unrestricted use, distribution, and reproduction in any medium for non-commercial use provided the original author and source are credited.

\section{INTRODUCTION}

The Indonesian nation is known to adhere to people's sovereignty. Sovereignty in the 1945 Constitution of the Republic of Indonesia Article 1 paragraph (2), it is emphasized that sovereignty is in the hands of the people and is implemented according to the Constitution. The people's sovereignty as mandated in Article 1 paragraph (2) of the 1945 Constitution of the Republic of Indonesia has a purpose, namely placing the people as having the highest power in exercising government power. The people are sovereign and the holder of the highest power in government [1]. One of the manifestations of the implementation of people's sovereignty in the context of administering the government is to give recognition to the people to participate actively in determining the form of the administration of the government.
The general election is a manifestation of the people's sovereignty in Indonesia. As a form of the democratic process, general elections are held by fulfilling the principles of direct, general, clean, honest, and fair. This is following the provisions of Article 22E of the 1945 Constitution of the Republic of Indonesia

Article 1 paragraph (17) of Law Number 7 of 2017 concerning General Elections explains that the Election Supervisory Body, hereinafter referred to as Bawaslu, is an election management body that oversees the implementation of elections throughout the territory of the Unitary State of the Republic of Indonesia. Supervision is carried out to prevent and take action against violations that occur in elections. Prevention is carried out by carrying out direct supervision of all stages of the election process. On the other hand, Bawaslu has the authority to take action. Take action by Bawaslu by 
providing recommendations to the competent institutions to follow up on violations that occur.

Article 1 paragraph (24) of Law Number 7 of 2017 concerning General Elections stipulates that the Honorary Council for Election Organizers, that abbreviated as DKPP, is the institution in charge of handling the implementation of the code of ethics for Election Organizers. DKPP as part of the Election Organizing Institution was formed to examine and decide on complaints or reports of alleged violations of the code of ethics. The alleged violations of the code of ethics reported were allegedly committed by KPU members, Provincial KPU members, Regency or City KPU members, Bawaslu members, Provincial Bawaslu members, and Regency or City Bawaslu members.

The case of Evi Novida Ginting [2] where in this case, the complainants argued that the complainants through the Selection Team for Candidates for KPU Members in Kolaka Regency and East Kolaka Regency, Southeast Sulawesi Province for the 2018-2023 period did not pass the complainants in the administrative stage because they used the recommendations of the Complainant's Personnel Guidance Officer (PPK). signed by the Daily Executive Secretary of the Southeast Sulawesi Province on behalf of the Governor of Southeast Sulawesi Province, even though there were several other candidates for members of the Regency KPU in Southeast Sulawesi Province declared to have passed using the same recommendation.

The decision of the DKPP RI on March 18, 2020, issued DKPP Decision Number 317-PKEDKPP/X/2019 which in essence imposed a permanent dismissal of Evi Novida Ginting Manik (KPU RI Commissioner), warning sanctions the last harsh words against the other commissioners of the KPU RI, and a warning sanction against each commissioner of the KPU for the province of West Kalimantan.

As a form of follow-up to the DKPP Decision Number 317-PKE-DKPP/X/2019, the President of the Republic of Indonesia has officially dismissed Evi Novida Ginting Manik from her position as Commissioner of the Indonesian KPU. Evi Novida Ginting filed a lawsuit to the Administrative Court against President Joko Widodo's Decree No. 34/P of 2020 which dismissed him dishonorably as an object of dispute in the PTUN.

The lawsuit for the dismissal of Evi Novida Ginting was completely granted by the Administrative Court and in this case, the Presidential Decree regarding the dismissal was postponed until the inkracht decision (with permanent legal force). The PTUN's authority to adjudicate lawsuits according to the Jakarta Administrative Court, although the DKPP's decision is final and binding, does not mean immunity to DKPP. There are empirical facts, namely the Decision of the
Constitutional Court (MK) No. 31/PUNDANG-XI/2013 which indirectly examines the DKPP's decision. Borrowing the consideration of the Constitutional Court, the final and binding nature of the DKPP decision only applies to the President, the General Election Commission (KPU), Provincial KPU, Regency/Municipal KPU, and the General Elections Supervisory Body (Bawaslu) that implement DKPP's decision [2].

The Administrative Court also blamed DKPP because DKPP did not take Evi's absence at the DKPP trial as a consideration. This eliminates the right and opportunity to file the right of self-defense. Article 19 of DKPP Regulation No. 3/2017 is alluded to in the legal considerations of the Administrative Court. In the PTUN's view, although Article 19 provides discretionary authority to continue or stop complaints that have passed material verification, but related to the provisions of Article 24 of the Government Administration Law, the implementation of the discretionary authority must be followed by several conditions, which is the reasons for continuing to be explained proportionally, rational and transparent. The Jakarta Administrative Court assessed that DKPP did not explain the reasons for continuing the complaint that had been revoked in DKPP's Decision No. 317.2019. In fact, according to the Administrative Court, this reason is even more critical in the context of the importance of ensuring the principle of justice for all parties, because Evi was not present at the trial at the DKPP to defend herself. Another argument described by the Jakarta Administrative Court is that DKPP overrules the DKPP's procedural law. Article 36 of DKPP Regulation No. 3/2017 states that a plenary meeting must be attended by a minimum of 5 members. This regulation is contrary to the Decree of the Chairman of DKPP No. 04/SK/K.DKPP/SET-04/I/2020 Regarding the Decision Making Plenary Meeting dated January 17, 2020, which stipulates that the decision plenary meeting can be attended by at least 4 DKPP members. The Administrative Court also explained that the presence of one DKPP member who changed public positions should not invalidate the fulfillment of the quorum requirements. The procedural law is not only a law that regulates the procedures for enforcing the rule of material law but also the essential embodiment of the rights of justice seekers to defend their interests, as well as limiting signs for any authority acting on behalf of the law.

Based on these considerations, the Jakarta Administrative Court believes that DKPP Decision No. 317/2019 contradicts Article 24 of Law No. 30/2014 concerning Government Administration and Article 458 paragraph (3), paragraph (4), paragraph (5), and paragraph (8) of Law no. 7/2017 concerning Elections as well as Article 36 of DKPP Regulation No. 2/2019. Because the Decision which is the basis for the issuance of the decision on the object of dispute contains a juridical defect, then the validity of the Presidential 
Decree is not legally fulfilled. The Jakarta Administrative Court granted Evi's request in its entirety. In fact, in its decision, the Jakarta Administrative Court also granted the request for a postponement of the implementation of the Presidential Decree which permanently dismissed Evi as a member of the Indonesian KPU for the 2017-2022 period.

Evi Novida Ginting's lawsuit which was fully granted by the Administrative Court made the President issue a decision to revoke the Presidential Decree on the dismissal of Evi Novida as a KPU member.The acceptance of Evi Novida's lawsuit by the Administrative Court proves that the existence of the DKPP as an institution that functions to uphold positive ethics and has been strengthened by the nature of its decisions that are final and binding, like the Constitutional Court, or other judicial institutions, is very easily broken.

Philosophically, if there is a problem with the enforcement of the code of ethics for election administrators, it will have implications for the implementation of elections and the integrity of the officials who were elected through the election. In the perspective of the ontology of this research problem, the nature of the DKPP's decision is unclear, because it creates problems. From an epistemological perspective, the problem is that the regulation of the nature of the DKPP's decision is not following the principles of electoral justice and certainty, so that at the axiological level, the existing condition of the DKPP's decision setting in Law no. 7 of 2017 concerning Elections, creates uncertainty and injustice for parties affected by the decision by the DKPP.

The DKPP decision is a decision that has an important relationship with the stages of the election so that in the future it is better for the legislators, the President, and the DPR to provide a room for ethical correction, not legal correction, for the DKPP decision in the Legislation on General Elections. The room for correction is assigned to the Ethics Court, which is the last place for justice seekers. This problem is what urges the author to study it further in a research with the main problem as follows:

1. What are the weaknesses in the regulation of ethics enforcement for general election organizers?

2. How is the reconstruction of ethics enforcement regulations for general election organizers based on dignified justice?

\section{METHOD OF RESEARCH}

This type of research is a kind of empirical juridical, or referred by field research that examines the provisions of applicable law and what happens in reality in society [3]. Juridical empirical research is legal research on the enactment or implementation of normative legal provisions in action at any particular legal event that occurs in society [4]. This research was conducted using a socio-legal approach: because this research focused on social and legal phenomena in society. The research paradigm used for this research is none other than philosophical assumptions or basic assumptions that are based on the Indonesian nation's perspective on existing legal issues, which is Pancasila.

\section{RESEARCH RESULT AND DISCUSSION}

\section{Weaknesses In The Regulation Of Ethics} Enforcement For General Election Organizers

Positive legal or ethical values have a very high position in the law. Values that ensure that Election Organizers conduct elections with dignity, comply with legal dictates through the Election Law (Law No. 17 of 2017), a law that is quite ideal following the will in the soul of the nation (volksgeist) [5] Indonesia comes from Pancasila as the source of all sources of law. Institutionally, the purpose of establishing the DKPP is to maintain the independence, integrity, and credibility of the KPU and Bawaslu so that the general election will run properly and correctly. To ensure that election organizers maintain their independence, integrity, and credibility, the DKPP in carrying out its duties focuses on implementing the principles of election management, including the principles of independence, honesty, fairness, legal certainty, orderliness, public interest, openness, proportionality, professionalism, accountability, efficiency, and effectiveness.

According to Soerjono Soekanto [6], law enforcement is not solely a function of implementing legislation, there are other influencing factors, namely legal factors, law enforcement factors, facilities or facilities factors, community factors, and cultural factors. The discussion on weaknesses in ethical enforcement for general election organizers will be reviewed from these five factors.

Law Enforcement Factors, An election organizer cannot convey the reason that they do not know the regulations or the legal basis of an election stage and the technical implementation so that they commit violations. Even though election organizers are new people who may not have experience as election organizers, they must be able to quickly adapt and learn about election administration. Regulations that change and change rapidly or even contradict each other are no reason for an election organizer to defend themselves that they have not studied and understood it. They should endeavor to coordinate and consult to carry out their duties and powers.

Abuse of duty and authority is frequently reported. Misuse of duties and authority can occur intentionally or unintentionally. Deliberately, because they know what they are doing is inappropriate or not based on the applicable rules, norms, and code of ethics, but they still do it because they are forced, threatened, or negligent. Unintentional, because they don't know, can't, and or don't understand. Whatever the reason, this problem is still considered a violation of the code of 
ethics, because an election organizer should understand and be able to carry out his duties and authority.

The problem of synergy between election organizers is a problem that is often faced by election organizers in carrying out their duties and authorities. The responsibility of election organizers is a collective collegial responsibility. Although each member has shared divisions, coordinators, and responsibilities, they cannot avoid moral mistakes made by other members if the problem is related to the duties and authorities of election participants by law. In the case of a code of ethics that appears, generally, the Election Organizing Honorary Council examines the error whether it is a personal error or a collegial collective error.

The last problem is the lack of understanding of the regional environment. An election organizer must understand the situation and condition of the geographical area, culture, social community, and conflicts that generally occur in their area. Ignorance of this can result in them being unprofessional in carrying out their duties under applicable regulations.

In terms of facilities and infrastructure, the DKPP Secretariat is under the coordination of the Ministry of Home Affairs, in particular the Organizational Unit of the Secretariat General of the Ministry of Home Affairs, so to meet the needs for internal facilities and infrastructure, DKPP is integrated with the Ministry of Home Affairs, according to the author, the DKPP budget should be under one roof with the General Elections Commission ( KPU) or the Election Supervisory Body (Bawaslu) rather than the Ministry of Home Affairs because the Ministry of Home Affairs is an institution directly under the executive leadership of the president. Thus, during the election process, it is very likely that there will be a conflict of interest between the executive leadership who is contesting and the interests of the contestation through DKPP. In this case, the president and ministers are from political parties.

However, the Ministry of Home Affairs is under the leadership of the executive, the president, and the Minister of Home Affairs, which of course during the election process is very likely to have a conflict of interest. The independence of DKPP has the potential to be injured. In addition, the potential for intervention from budgetary politics and personnel due to double loyalty and internal conflicts of DKPP members. Pressure and intervention can come from budget and personnel politics due to dual loyalty. The current position of DKPP, for example, could be an entry point for the politicization of DKPP associated with the election contestation and the existence of the interests of the parties that carry the government [7].

On Community Factors, the Election Organizers Honorary Council (DKPP), which is one of the election organizers, has the noble task of enforcing the code of ethics for election organizers. The success of implementing a law cannot be separated from the good and bad of the legal regulations that are made. DKPP as an institution mandated by law to enforce the code of ethics for election organizers is carried out with the principles of being fast, open, and simple.

Allegations of violation of the code of ethics can be submitted to DKPP based on Article 4 paragraphs (1) and (2) of DKPP Regulation Number 1 of 2021 concerning the Second Amendment to the Regulation of the Honorary Council of General Election Organizers Number 3 of 2017 concerning Guidelines for Proceedings. Code of Ethics of General Election Organizers determines the subject of the complainant in handling allegations of violations of the code of ethics for election organizers, among others, Election Organizers, Election Contestants, Campaign Teams, Community and/or Voters, as well as complaints and/or reports of alleged violations of the code of ethics originating from the recommendations of the DPR.

In this context, the DKPP solely functions as a judiciary (enforcer) of ethics, not as a supervisor as well as an ethical enforcer. The problem is what if in organizing this election there are many ethical violations committed by the election organizers, but there are no complaints and or reports and recommendations from the DPR. For example, the alleged violation is only reported in the media, and or there are allegations of violations of the code of ethics committed by the organizers through print and electronic media that are known to the DKPP, but there are no complaints and/or reports and recommendations from the DPR, so ethical enforcement is impossible because DKPP is not given the authority to supervise and make an alleged ethical violation a finding.

In the last factor, which is the Cultural Factor, to declare a behavior of good value, then there must be a comparison in the form of behavior of bad value displayed by the same subject. This also applies when stating the behavior of an election organizer is said to be of good value or vice versa of bad value. An Election Organizer is considered to have good behavior when taking actions or making decisions according to the basic ethical principles that have been set (according to Article 11 of the Joint Regulations of the KPU, BAWASLU, and DKPP No. 2 of 2017. If the Election Organizer implements the Election Law, enforcement the principle of legal certainty must be based on the provisions of Article 11 letter $\mathrm{d}$ of the Joint Regulation of the KPU, $B A W A S L U$, and DKPP regarding the Code of Ethics for Election Organizers, which is the obligation to ensure that the implementation of laws and regulations relating to elections is fully implemented impartially and fairly and fairness is closely related to ethical standards in the context of implementing the principle of justice as stated in Article 10 letter b of the Joint Regulation of the KPU, $B A W A S L U$, and DKPP concerning the Code of Ethics for 
Election Organizers, that is treating every candidate, election participant, prospective voter, and other parties equally involved in the electoral process. Thus, the obligation to uphold the principle of legal certainty in the sense of ensuring the implementation of the Election Law is fully implemented impartially and fairly, basically also upholding the principle of justice - in the sense of treating every candidate, election participant, candidate voter, and other parties involved equally in the electoral process.

\section{Reconstruction of Ethics Enforcement Regulations for General Election Organizers Based On Dignified Justice}

The first reconstruction offered by the author is to revise Article 458 paragraph (13) of Law no. 7 of 2017 concerning Elections. According to the author's view that in order not to give rise to various interpretations, the final and binding phrases should be removed. After the editorial addition of the Inkracht decision, it is continued by replacing the material content that is placed on the Explanation Sheet regarding the meaning of Article 458 paragraph (14) of the Law. Law No. 7 of 2017 concerning Elections.

According to the author of Article 458 of Law no. 7 of 2017 concerning Elections, which originally consisted of 14 paragraphs, was increased to 17 paragraphs, with details that there is one paragraph that has undergone editorial corrections, namely paragraph (13), and there are additional four new paragraphs in this study, namely paragraph (14). ), verse (15), verse (16), and verse (17). Starting from this explanation, the total number of Article 458 becomes 17 (seventeen) paragraphs, so that to make it easier for readers to understand the author's main thoughts regarding the editorial of the article that regulates the DKPP decision, the author will sequence the relevant paragraphs, starting from Article 458 paragraph (10) to paragraph (17).

Based on the results of the study, the authors found that legal remedies addressed to the State Administrative Court (PTUN), carried out by election organizers who had been terminated by the DKPP went through too long stages, and at each stage that was passed there was no certainty regarding what is the strength of the decision. The stages in the lengthy State Administrative Court (PTUN) as referred to can be found, one of which is the Decision to Dismiss KPU for South Konawe Regency, Southeast Sulawesi Province [8].

The case stems from an alleged violation of the code of ethics, which was then processed in the DKPP trial, during the trial process the DKPP assessed that the South Konawe Regency KPU was proven to have violated the code of ethics, and the DKPP dismissed the two commissioners of the Regency KPU. Two Regency KPU commissioners made an effort to the State Administrative Court (PTUN), wherein short, the efforts of the South Konawe Regency KPU to the State
Administrative Court (PTUN) won, but there was an appeal from the Provincial KPU as the party that issued the dismissal decision to the High Court. TUN, the TUN High Court won the Regency KPU and ordered it to return to its original state. The Provincial KPU made an appeal from the Supreme Court, and in the Supreme Court's decision ordered the restoration of the rights of the Konawe Regency KPU commissioner to its original state, but the Supreme Court's decision was not executed (nonexecutable). Based on the results of the first research because the Provincial KPU will be afraid of DKPP when they want to execute the decision of the State Administrative Court (PTUN), because re-activating election organizers that have been terminated DKPP will be constructed as a form of violation of the new code of ethics, and the findings according to the author will increasingly move away from the principle of simple justice, fast and low cost. According to the author, it will be simpler, faster, and less costly when ethical efforts are entrusted to one door, which is the Ethics Court because as the author explained in the previous discussion, the Ethics Court's decision is final and binding. And the second important reason is that law violations and ethical violations are 2 different things. So it is not appropriate when ethical violations are handled by a legal court [9].

Reconstruction in Law no. 9 of 2004 concerning Amendments to Law no. 5 of 1986 concerning the State Administrative Court. The reconstruction offered by the author is by adding criteria or types of decisions that are not included as objects that can be submitted to the State Administrative Court (PTUN). The arrangement regarding objects that cannot be submitted to the State Administrative Court (PTUN) is found in Article 2 of Law no. 9 of 2004 concerning amendments to Law no. 5 of 1986 concerning the State Administrative Court.

In Article 2 of Law no. 9 of 2004 concerning amendments to Law Number 5 of 1986 concerning the State Administrative Court, there are 7 (seven) decisions that are excluded, so they cannot be used as objects in the State Administrative Court (PTUN), Based on the seven excluded decisions above, then the author recommends adding one more criterion, which will be placed in Article 2 letter h.

Based on the results of the author's observation in the lawsuit filed in the State Administrative Court (PTUN), the dismissed plaintiff or election organizer will describe what is meant by causing legal consequences for a person or civil legal entity. Where the plaintiff often defines that causing legal consequences, in this case, means causing a change in the atmosphere of the existing legal relationship. The decision on the dismissal of the election administrator will cause a change in the legal relationship for the person who has been dismissed. With the issuance of the dismissal decision, the person who se name is listed in the decision will stop as an election organizer. And after the issuance of the dismissal decision, the person who was dismissed no longer has the 
duties, authorities, and obligations as an election organizer. Thus, the dismissal decision that has resulted in legal consequences for a person has been fulfilled [10].

Based on the sequence of arguments above, the State Administrative Court (PTUN) will accept and be of the view that the subject matter of the lawsuit falls within the jurisdiction of the State Administrative Court (PTUN). Starting from this, to find a solution to the legal arguments used by election organizers who have been dismissed but intend to file a lawsuit with the State Administrative Court (PTUN), then enter the Presidential Decree, the General Election Commission, the Provincial General Election Commission, Bawaslu, The Provincial Bawaslu issued based on the decision of the Election Organizing Honorary Council for violations of the code of ethics committed by the election organizers as a type of decision that cannot be filed with the TUN Court is a solution idea.

This idea at the same time closes the gap, when there is a legal argument that the article that requires courts is prohibited from refusing to examine, hear, and decide on a case submitted on the pretext that the law does not exist or is unclear, but is obliged to examine and try it. More clearly, the following is the sound of Article 10 paragraph (1) of Law Number 48 of 2009 concerning judicial power, which means "The court is prohibited from refusing to examine, try, and decide on a case submitted on the pretext that the law does not exist or is unclear, but obliged to examine and try it".

Therefore, based on the description above, the reconstruction as intended by the author is as follows:

1. Article 458 paragraph (13) of Law no. 7 of 2017 concerning Elections changes to: "The decision as referred to in paragraph (10) is final and binding on the President, KPU, Provincial KPU, Bawaslu, and Provincial Bawaslu if there is a decision to resign".

2. Explanation sheet that explains Article 458 paragraph (14), namely: (1) in the mandatory word phrase, to synchronize/connect the author's ideas, the phrase of the election organizer's obligation has conditions that must be met, namely the decision that has been issued by the DKPP in a condition not there are ethical efforts made by the parties so that if there are still parties who make ethical efforts, the election organizers must postpone the implementation of the DKPP decision. (2) the address (address) of the institution that will implement the DKPP decision is not only the election organizer but also addressed to the President because if the DKPP decision decides on the dismissal of the KPU or the central Bawaslu, the one who has the authority to follow up on the DKPP decision is the President because The president issues the appointment letter for the KPU and the central Bawaslu. Based on this, the authors add the phrase President in the Article that regulates the implementation of the DKPP decision.
3. Article 2 of Law no. 9 of 2004 concerning the State Administrative Court, there are 7 (seven) decisions that are excluded, namely: (2) State administrative decisions which are general arrangements. then the author recommends adding one more criterion, where the criteria will be placed in Article 2 letter $h$ whose editorial is as follows: "Decision of the President, General Election Commission, Provincial General Election Commission, Bawaslu, Provincial Bawaslu issued based on the order of the Honorary Election Organizing Council's decision. for violations of the code of ethics committed by election organizers."

\section{CONCLUSION}

1. Weaknesses in enforcing ethics for general election organizers, namely:

a) Legal Factors:

Measures of the quality of evidence in the DKPP trial, The procedural law of the trial at DKPP is not regulated regarding the complete order of evidence, there are rules regarding evidence but it is only intended for the Complainant as a formal requirement to file a complaint with the DKPP, where witness statements are first in the list of evidence that must be submitted. The quantity of evidence presented by the Complainant is less than that presented by Defendant. However, the matter of proof at trial, the quantity of evidence of letters/documents is not a guarantee, for that there must be witnesses because witness statements are the first place in the order of evidence in DKPP.

b) Law Enforcement Factor

1. Abuse of duties and authority can occur intentionally or unintentionally.

2. The problem of synergy between Election Organizing institutions is a problem

3. Lack of understanding of the regional environment

c) Facilities and infrastructure factors

d) Community Factor

There are many ethical violations committed by election organizers, but there are no complaints and or reports and recommendations from the DPR because ethical enforcement is not possible if the DKPP is not given the authority to supervise and make an alleged ethical violation a finding.

e) Cultural Factor

The differences in political culture that develop in society are influenced by several factors, including: (1). The level of public education is the main key to the development of the political culture of the community. (2). The economic level of the community; The higher the level of economy/prosperity of the community, the greater the participation of the community. (3). Political reform/political will (the spirit of revising and adopting a better political system). (4) The rule of law (the existence of fair, independent, and free law enforcement). (5) Independent communication media (functioning as social control, free, and independent). 
2. Reconstruction of Ethical Enforcement Regulations for Organizers of General Elections Based on Dignified Justice Values are:

a. Amend Article 458 paragraph (13) of Law no. 7 of 2017 concerning General Elections which in the author's view that in order not to give rise to various interpretations, the final and binding phrases should be removed.

b. Substituting on the material content that is placed on the explanation sheet of Article 458 paragraph (14) of Law no. 7 of 2017 concerning Elections, which states that election organizers are required to implement DKPP decisions. (1) in the mandatory word phrase, to synchronize/connect the author's ideas, the phrase of the election organizer's obligation has conditions that must be met, which is the decision that has been issued by the DKPP in the condition that there are no ethical efforts made by the parties so that if there are still who make ethical efforts, the election organizers must postpone the implementation of the DKPP decision. (2) the address (address) of the institution that will implement the DKPP decision is not only the election organizer but also addressed to the President because if the DKPP decision decides on the dismissal of the KPU or the central Bawaslu, the one who has the authority to follow up on the DKPP decision is the President because The president issues the appointment letter for the KPU and the central Bawaslu. Based on this, the authors add the phrase President in the Article that regulates the implementation of the DKPP decision.

c. Article 2 of Law no. 9 of 2004 concerning the State Administrative Court, the author recommends adding one more criterion, where the criteria placed in Article 2 letter (h)

\section{REFERENCES}

1. Bima, A. A. N. A. W. (2019). Pemilihan Umum Indonesia Antara Demokrasi Pancasila Dan
Demokrasi Liberal. Jurnal Ilmiah Cakrawarti, 2(2), 10-18.

2. Fitria, C. F. (2020). Jalan Panjang Evi Novida hingga Kembali Jadi Komisioner KPU Setelah Dipecat..., Taken From: https://nasional.kompas.com/read/2020/08/25/09404 441/jalan-panjang-evi-novida-hingga-kembali-jadikomisioner-kpu-setelah-dipecat?page $=$ all, $\quad$ on 19 December 2021.

3. Faisal. (2010). Menerobos Positivisme Hukum. Rangkang Education, Yogyakarta.

4. Pratama, T. G. W. (2020). The Urgency for Implementing Crytomnesia on Indonesian Copyright Law. Saudi Journal of Humanities and Social Sciences, 5(10), 508-514.

5. Malley, M. (2000). Beyond democratic elections: Indonesia embarks on a protracted transition. Democratization, 7(3), 153-180.

6. Soerjono, S. (2019). Faktor-Faktor Yang Mempengaruhi Penegakan Hukum, 16th Edition, Rajawali Pers, Depok, p.5.

7. Sabrina, D. F., \& Ristawati, R. (2021). The Implementation of Good Governance In The Presidential Election In Indonesia. Yuridika, 36(2), 281-294.

8. Liputan6.com. (2017). Jadi Terdakwa Korupsi Ketua Kри Konawe Selatan Segera Nonaktif, taken from konaweselatan.kpu.go.id/berita/jadi-terdakwakorupsi-ketua-kpu-konawe-selatan-segera-nonaktif, On 9 December 2020.

9. Widodo, W., Budoyo, S., \& Pratama, T. G. W. (2021). Analysis of Regional Election amidst Covid19 Pandemic in Semarang City. JL Pol'y \& Globalization, 108, 22. https://heinonline.org/HOL/LandingPage?handle=he in.journals/jawpglob108\&div=5\&id=\&page $=$

10. Widodo, W., Budoyo, S., \& Pratama, T. G. W. (2018). The role of law politics on creating good governance and clean governance for a freecorruption Indonesia in 2030. The Social Sciences, 13(8), 1307-1311. 